Larsen, A.K. (2016). En alternativ læringsarena.

Scandinavian Journal of Vocations in Development.

http://dx.doi.org/10.7577/sjvd.1848

Fagfellevurdert artikkel

\title{
En alternativ læringsarena
}

\section{Forfatter:}

\section{Anne Karin Larsen ${ }^{1}$}

${ }^{1}$ Høgskolen i Oslo og Akershus, Fakultet for lærerutdanning og internasjonale studier, Institutt for yrkesfaglærerutdanning, Postboks 4, St. Olavs plass, N- 0130 Oslo.

annekarin.larsen@hioa.no

Nøkkelord: Sosial entreprenør, forankring, praksisfellesskap, relevans, motivasjon, læringsevne 


\section{Abstrakt}

Interessen for pedagogisk entreprenørskap og samarbeid med eksterne aktører har vært økende de siste årene. Den videregående skolen er åpen for alle elever med ulike læreforutsetninger. Yrkesfaglærerne møter derfor store utfordringer knyttet til elevers interesse og motivasjon.

Artikkelen handler om et samarbeid mellom en liten sosial entreprenørbedrift og et yrkesfaglig utdanningsprogram på en videregående skole i Midt-Norge. Studien belyser problemstillingen: Bidrar en alternativ læringsarena, der yrkesfaglærer og sosiale entreprenører samarbeider, til $ø k t$ motivasjon hos elever? I så fall, hvordan?

Basert på data fra en saksstudie ser artikkelen nærmere på et samarbeid mellom en yrkesfaglærer og en arbeidsleder i en sosial entreprenørbedrift. Studien har en kvalitativ tilnærming basert på et strukturert litteratursøk, to dybdeintervjuer med yrkesfaglæreren og arbeidslederen, og analyse av et utviklingsarbeid utført av en yrkesfaglærer.

Resultatet viser at elevene tok tydelig ansvar for egen læring i sitt arbeid hos den sosiale entreprenøren, men dette påvirket ikke deres fremmøte på skolen. De fortsatte med den tidligere observerte passive adferden, og uteble fra deler av undervisningen. Basert på studiens funn konkluderes det med at forankring og en felles forståelse for læringsprosessen kan oppfattes som en mulig suksessfaktorer. Det anbefales at utvikling av samarbeidskompetanse mellom lærer og bedrift vektlegges i stor grad i yrkesfaglærerutdanningen. 


\section{Abstract}

Interest in pedagogical entrepreneurship and collaboration with external actors has been on the increase in recent years. All young people leaving compulsory school have a statutory right to Upper secondary education regardless of their learning abilities. Teachers therefor face considerable challenges with regard to learners' interest and motivation. The article addresses a partnership between a small social entrepreneur company and a vocational education and training programme (VET) in an Upper secondary school in central Norway. The research question is: Can an alternative learning arena, where a vocational teacher and a social entrepreneur collaborate, contribute to increased motivation for pupils? If so, how? Based on data from a case study the article examines collaboration between a vocational teacher and a supervisor in a social entrepreneur company. The study`s research approach is qualitative and based on a structured literature search, two in-depth interviews with the vocational teacher and the company supervisor, and an analysis of the development work carried out by the vocational teacher. The results show that learners clearly took responsibility for their own learning whilst working with the social entrepreneur, but that this did not have an effect on their school attendance. They continued with their previously observed passive behaviour and absenteeism from lessons.Based on the findings, it can be concluded that the embedment and a common understanding of the learning process may be seen as possible success factors. It is recommended that development of cooperative skills between teachers and companies should be given prominence in Vocational Teacher Education.

Keywords: Social entrepreneur, embedment, community of practice, relevance, motivation, learning ability, learning process.

\section{Innledning}


Det er viktig at ungdom opplever seg som en del av samfunnet, at de bidrar til fellesskapet gjennom deltagelse og opplevelse av mestring (Lave \& Wenger 2004; Meld. St. 20, 20122013; Wenger 2009). Elevers gjennomføring av videregående opplæring spiller en avgjørende rolle for hvordan de lykkes i arbeidslivet (Lødding \& Holen 2013). Stort frafall i videregående skole får derfor følger ikke bare for den enkelte elev. Det påvirker også samfunnet, blant annet ved at verdifull og nødvendig kompetanse går tapt (Stamsø 2012). Forskning om frafall og gjennomføring (Markussen \& Seland 2012) setter søkelyset på hvor viktig det er at læring blir tilrettelagt for den enkelte elev. Det understrekes også at alternative læringsarenaer kan være et nyttig supplement til tradisjonelle skolebaserte læringsformer.

Elevenes indre motivasjon reduseres med økt antall skoleår (Katz, Kaplan \& Gueta 2009). Når elevene blir eldre, vil de søke mer uavhengighet og selvstendighet i arbeidet. Samtidig vil de fortsatt trenge sosial støtte gjennom relasjoner med voksne. Hvis overgangen fra grunnskolen til videregående skole innebærer mer selvstendighet og mindre lærerstøtte, kan dette redusere motivasjonen. Slik støtte blir særlig viktig for elever som har liten voksenkontakt utenom skolen (Katz et al. 2009). Internasjonal og norsk forskning på motivasjon peker på at elevens oppfatning av læreren eller yrkesutøveren i praksis har mest betydning når det gjelder elevens motivasjonen for skolearbeid og læring (Hattie 2009; Overland \& Nordahl 2013; Patrick, Ryan \& Kaplan 2011).

\section{Samarbeid om alternative loeringsarenaer}

Interessebasert differensiering og yrkesretting av fellesfagene øker elevenes motivasjon og interesse for yrket og for egen læring (Sylte, Haaland, Hansen \& Dahlback 2011). Disse forholdene gjenspeiles i stortingsmeldingen På rett vei (Meld. St. 20, 2012-2013), der det åpnes for differensiert undervisning og for en ny organisering av utdanningsløpene. I etterkant av denne meldingen har Utdanningsdirektoratet satt $\mathrm{i}$ gang forsøk og forskningsprosjekter der en prøver ut en ny yrkesdidaktikk og nye samarbeidsformer mellom institusjoner og arbeidsliv. Disse prosjektene viser at aktørene ser behovet for alternative læringsarenaer, men at arbeidslivet i mange tilfeller ikke kan tilby et tilstrekkelig antall læreplasser (Høst, Nyen, Reegård, Seland \& Tønder 2015).

I Lærlingundersøkelsen 2014, basert på 11332 lærlinger og lærerkandidater, ligger snittet for tilfredshet med skolen som forberedelse til lære på 3,51 av 5. Snittet for opplevd motivasjon, sosial trivsel og støtte på arbeidsplassen ligger på 4,5 av 5. For elever i tilrettelagt 
opplæringssituasjoner, som ikke ser for seg at de klarer å gjennomføre fag- eller svennebrev, fungerer de alternative oppleggene etter hensikten (Caspersen, Garvik \& Wendelborg 2015).

Hva de unge bærer med seg av kunnskaper og holdninger når de begynner i videregående skole har stor betydning for deres utdanning. Jensen og Larsen (2011) viser til forhold som har betydning for frafall i skolen. Skolene har ulikt frafall, noe som ofte avhenger av samarbeidet mellom skole og nærmiljø. Jensen \& Larsens forskning på danske skole viser at dette ikke er et særnorsk problem, men en utfordring også for andre skandinaviske land.

\section{Innovasjon i yrkesfag - et studietilbud ved Høgskolen i Oslo og Akershus}

Høgskolen i Oslo og Akershus (HiOA) er Norges største statlige profesjonshøgskole med 17500 studenter og 1900 ansatte. Skolen jobber tett med studenter, profesjoner og arbeidsliv, og består av 19 institutter fordelt på fire fakultet samt flere forskningssentre. Institutt for yrkesfaglærerutdanning (YLU), tilbyr master i yrkespedagogikk, bachelor i yrkesfaglærerutdanning (YFL) og flere relevendte videreutdanninger for yrkesfaglærere. Studiet Innovasjon i yrkesfag, som denne casestudien er basert på, er et videreutdanningsstilbud innen pedagogisk entreprenørskap på YLU for yrkesfaglærere. Studentene er til daglig ansatt som lærere på yrkesfaglige utdanningsprogram i den videregående skolen. Arbeidsformen i studiet består i å gjennomføre et yrkespedagogisk utviklingsarbeid og studentene har et felles mål - å videreutvikle pedagogisk praksis. Deres ønske baserer seg på egne erfaringer som lærere, spesielt knyttet til det å tilrettelegge undervisning i klasser hvor mange av elevene ikke viser særlig faglig interesse. Yrkesfaglærerne fortalte om stort fravær. Ulike problemer som ikke kunne relateres til undervisningen var de vanligste årsakene. De gav uttrykk for et ønske om å kunne legge til rette for alternative læringsarenaer med differensiert undervisning. Tilbudet skulle ta utgangspunkt i begrep som relevans, elevmedvirkning og praksisfellesskap (Wenger, 2009).

\section{Mål og forskningsspørsmål}

Hensikten med denne studien er å undersøke en alternativ læringsarena der målet er å øke motivasjonen hos elevene. Studien ønsker å se på samarbeidet mellom en skole og en sosial entreprenør. Målet er å se om samarbeidet kan bidra til at elevene får økt motivasjon for læring og arbeid. Problemstillingen blir dermed: «Bidrar en alternativ læringsarena, hvor yrkesfaglærer og sosiale entreprenører samarbeider, til økt motivasjon hos elever? I så fall, hvordan?» Overordnet handler problemstillingen om yrkesfaglærerens kompetanse, hvordan 
den kan utvikles igjennom samarbeid med sosiale entreprenører. Den handler også om hvordan vi kan legge til rette for gode læringsprosesser på en alternativ arena.

\section{Metode}

Undersøkelsen ble utformet som saksstudie (Patton 2002), der vi undersøker noen få variabler i en dyptgående analyse. Datamaterialet baserer seg på et litteratursøk, to dybdeintervjuer og analyse av et utviklingsarbeid (yrkesfaglærerens rapport). Saksstudien bygger på en fenomenologisk tilnærming som har som mål å analysere sosiale fenomener ut fra aktørenes perspektiv. Virkeligheten blir beskrevet slik informantene opplever den (Kvale, Brinkmann, Anderssen \& Rygge 2009). Dette er forankret i kognitiv- og sosialkonstruktivistiske læringsteorier, hvor det fokuseres på deltakernes individuelle opplevelser av læringsprosessen, med særlig vekt på samspillet mellom aktørene i praksisfellesskapet (Lave 2009; Wenger 2009).

\section{Litteratursøk}

Det ble foretatt et litteratursøk (Patton 2002) basert på nøkkelordene videregående skole, frafall, elevenes behov (students needs), laererstøtte (teacher support), motivasjon (motivation), sosial entreprenør (social entrepreneur) i basene ORIA, NORART og ERIC. Først ble det tatt utgangspunkt i emneordene students needs, teacher support, motivation. Dette utgjorde «grunnblokken» i søket. Videre ble dette kombinerte med dropout* (i betydning school dropouts) og meaningful* (meaningful education, meaningfulness). Søkeordene ble kombinert med boolske operatorer AND og OR og søket var avgrenset til siste 10 år, dvs. 2005-2014. Søket ga 49 fagfellevurderte artikler på engelsk hvorav 2 ble inkludert i artikkelen. Gjennom søk på varianter av norske og engelske søkerord fant jeg en del relevant grått materiale (avhandlinger, forskningsrapporter, antologier og faglitteratur etc.) som ble inkluderte i artikkelen.

\section{Dybdeintervjuer}

Det ble foretatt to dybdeintervjuer, ett med yrkesfaglæreren og ett med arbeidslederen i bedriften. Yrkesfaglæreren var ansatt i full stilling ved en videregående skole, og var lærer for to elever på utdanningsprogrammet media- og kommunikasjon. I tillegg var hun deltidsstudent på studiet Innovasjon i yrkesfag. Hun ønsket gjennom sitt utviklingsarbeid å gi elevene muligheten til å lære på en alternativ læringsarena. I artikkelen betegnes hun som 
yrkesfaglæreren, selv om hun utførte utviklingsarbeidet som student, og dokumenterte utviklingsarbeidet i en rapport til eksamen.

Samarbeidspartneren, eieren av den alternative læringsarenaen, ble i dette tilfelle en liten nystartet bedrift. Valg av sosial entreprenørskapsbedrift hadde bakgrunn i at yrkesfaglæreren kom i kontakt med eieren av bedriften på et seminar om sosialt entreprenørskap (Ingstad \& Loga 2016), og de gjorde en direkte avtale om å samarbeide. Arbeidet i bedriften går ut på å innhente glass fra husstander etter en abonnementsordning. Det som skiller denne bedriften fra en annen ordinær bedrift, og gjør den til en sosial entreprenør, er at arbeidstakerne i bedriften er tidligere rusavhengige på vei tilbake til arbeidslivet. Hensikten er ikke primært økonomisk, men sosial verdiskapning. Bedriften er likevel avhengig av inntjening, og drives etter vanlige prinsipper for forretningsdrift. De ønsket er å utvikle en informasjonsvideo om bedriftens tilbud av tjenester utført av tidligere rusavhengige.

I bedriften ble mottak og oppfølging av elevene delegert til en arbeidsleder. Han fungerte som yrkesfaglærerens kontaktperson i den tiden elevene arbeidet i bedriften. I artikkelen brukes betegnelsen arbeidslederen.

De to elevene i studien var elever på utdanningsprogrammet Media og kommunikasjon på en videregående skole i Midt-Norge. De hadde stort fravær, og lærernes erfaring var at de viste lite interesse for arbeid og læring på skolen. Yrkesfaglæreren hadde lite grunnlag for å vurdere elevene, og ønsket å legge til rette for en alternativ læringsarena. Yrkesfagelevene ble spurt om de ønsket å ta oppdragspraksis ved å lage videoen for den sosiale entreprenørskaps bedriften. I artikkelen brukes betegnelsen elever på de lærende. Betegnelsen laererarbeid brukes både på yrkesfaglærerens arbeid med læring av elever, og arbeidslederens arbeid med læring av arbeidstakere og elever i bedriften.

Intervjuguiden inneholdt to spørsmål. Disse spørsmålene var:

- Kan du beskrive i detalj en situasjon som du mener elevene lærte mye av da de var i oppdragspraksis i bedriften?

- Kan du beskrive i detalj en situasjon i dette samarbeidet som du mener du lærte mye av og som du vil ta med deg videre i ditt lærerarbeid?

Dataene som kom fram gjennom disse spørsmålene representerer kun yrkesfaglæreren og arbeidslederens erfaringer, deres tolkning av samarbeidsprosessen og elevenes deltagelse i arbeidet. 
Informantene, yrkesfaglæreren og arbeidslederen, skulle beskrive sine opplevelser og tolkninger av arbeidet og læringen på den alternative læringsarenaen hos den sosiale entreprenøren. Intervjuene ble gjennomført på informantenes arbeidsplass, og tok omtrent 30 minutter. Intervjuene begynte med det første åpne spørsmålet: «Beskriv detaljert en situasjon som du tror elevene lærte mye av.» Informantene valgte selv hva de ville fortelle, og etter at det første spørsmålet var stilt og læring var introdusert som tema for samtalen, fulgte jeg opp med spørsmål som tok utgangspunkt i informantens fortelling. Deretter stilte jeg det andre spørsmålet.

Intervjuene ble tatt opp elektronisk og senere transkribert. Sammen med den skrevne rapporten ble dette datagrunnlaget for innholdsanalysen. Elevene ble ikke intervjuet, men deres stemmer tolkes og gjengis av yrkesfaglæreren og arbeidslederen gjennom deres formidling fra samtalene med elevene. Resultatene er meningsfortettet og drøftet $\mathrm{i}$ et yrkesdidaktisk og sosiokulturelt perspektiv (Askerøi \& Høie 2012; Bandura 1997; Hiim 2013; Hiim \& Hippe 2001; Katz et al. 2009; Kolb 2012; Lave 2009; Manger, Hansen \& Nordahl 2012; Sylte et al. 2011; Wenger 2009) sammen med mine egne erfaringer. Hensikten med studien er å belyse et samarbeid mellom en yrkesfaglærer og en sosialentreprenør om undervisningen av to elever.

\section{Utviklingsarbeid}

Utviklingsarbeidet ble gjennomført våren 2014. Det er basert på en gjennomføringsperiode på fem måneder, og dokumenteres med en rapport (Yrkesfaglærerens rapport). Rapporten beskriver bakgrunn og hensikt med alle ledd i prosessen, og drøfter resultater og videre fremdrift av yrkesfaglærerens arbeid for høsten 2014. Rapporten er yrkesfaglærerens eksamensarbeid på studiet Innovasjon i Yrkesfag. I denne artikkelen refereres den til som Yrkesfaglærerens rapport.

\section{Førforståelse}

Forfatteren har vært yrkesfaglærer siden 90- tallet, og hadde i utgangspunktet før denne studien en førforståelse om at enhetsskolen ikke yter likeverdig opplæring. Mange elever i den videregående skolen ønsker ikke å være «elever» i skolen med dagens ordning. Organiseringen av undervisningen møter ikke alle elevers behov (Lillejord 2015). Elever har behovet for å bli behandlet som likeverdige, å bli sett og vist forståelse for egen situasjon. Mange elever savner samtidig at det stilles krav som den enkelte forstår og ser konsekvensene av. 
Ungdomstiden oppleves for mange som turbulent (Katz et al. 2009; Lillejord 2015; Markussen 2010; Markussen \& Seland 2012). Ofte er utfordringen at ungdom trenger å finne balansen i seg selv gjennom samarbeid med voksne (Katz et al. 2009), oppleve mestring av de små oppgavene før de kan gå videre. Dette har blitt tatt opp under årlige nasjonale konferanser $\mathrm{i}$ Ferd. Arbeidet til sosiale entreprenører fører til at ungdom som har falt ut av skolen viser økt trivsel på alternative læringsarenaer. Dermed kan de motiveres for skolegang eller arbeid (Ferd 2013; Sandal 2007) .

Loereforutsetninger er et sammensatt begrep, og kan defineres som de psykiske, fysiske og sosiale ressursene eleven møter skolen med (Hiim \& Hippe 2009:33). «Det er ikke skolens rolle å drive terapi, men det er skolens rolle å differensiere undervisningen og legge til rette for alle elevers læring. Vi får de elevene vi fortjener», sa Jens Bay i et foredrag på TAMU-senteret i København 2012. Hans utsagn kan tolkes som at elevene er et produkt av vår tids samfunn, av vår utdanning- og sosialpolitikk. Vi må sammen ta ansvaret for at alle inkluderes og opplever seg selv som nyttige for fellesskapet. Hiim og Hippe (2009:32-33) uttrykker det slik; «Det er skolen som må tilpasse seg elevene og ikke elevene som må tilpasse seg skolen. Den videregående skolen er åpen for alle, derfor må vi ta imot elevene slik de er og ikke kaste bort tiden med å tenke på hvordan de burde være.»

I senere år har Kunnskapsdepartementet initiert mye yrkesdidaktisk utviklingsarbeid og forskning i skolen (Kunnskapsdepartementet, [2013]). Målet har vært å øke elevenes motivasjon og evne til å gjennomføre videregående opplæring (Helgøy \& Homme 2013). Det satses i dag stort på yrkesretting og relevans i fellesfagene og programfagene. Blant annet blir det utviklet metoder for bedre læring og differensiering i undervisningen gjennom Prosjektet yrkesretting og relevans (FYR) (Helgøy \& Homme 2013; Stene, Haugset \& Iversen 2014) og faget Prosjekt til fordypning (PTF) (Kunnskapsdepartementet 2013).

Når det gjelder den relativt store gruppen som har problemer ikke relatert til yrkesvalg og relevans i opplæringen (Markussen \& Seland 2012), men til forhold utenfor skolen, mener jeg det ikke har vært satt inn store ressurser. Skolen og yrkesfaglærerne må derfor tenke nytt og være innovative i sin didaktikk for å nå denne gruppen. 


\section{Etisk vurdering og validitet}

Prosjektet ble lagt fram for Norsk samfunnsvitenskapelig datatjeneste AS (NSD). Innhenting og behandling av data ble foretatt $\mathrm{i}$ henhold til nasjonale etiske retningslinjer og anbefalinger gitt av NSD.

Empirien i studien er liten, det er derfor ikke mulig å generalisere ut fra den. Studien ha derfor kun en begrenset ekstern validitet, overførbarhetsverdi. Den interne validiteten dreier seg ifølge Grønmo (2004:233) om «hvorvidt eksperimentet i seg selv er gjennomført på en tilfredsstillende måte, slik at konklusjonen om årsakssammenhengen er gyldig under de kontrollerte undersøkelsesbetingelsene». Hensikten med en kvalitativt saksstudie er først og fremst å forklare hvorfor noe er tilfelle innenfor en konkret sak, ikke å teste ut teorier eller generalisere funn, snarere å opparbeide en helhetlig forståelse av saken som undersøkes (Grønmo 2004). På denne bakgrunnen mener jeg studien har god intern validitet.

Kompetansevaliditet handler om forskerens kompetanse til å innhente kvalitative data. Relevant kompetanse vil være forskerens erfaringer, kvalifikasjoner og forutsetninger til å samle inn denne typen data på det aktuelle fagfeltet (Grønmo 2004:234). Basert på denne definisjonen vil min erfaring som yrkesfaglærer og førstelektor i yrkespedagogikk, med utstrakt kunnskap om de problemstillingene og utfordringene lærere i dag står ovenfor, bidra til styrket kompetansekvalitet. Validiteten avhenger også av forskerens mulighet til å utvikle et nært forhold til informantene, slik at det blir mulig å samle inn den mest relevante informasjonen for problemstillingen (Grønmo 2004).

Yrkesfaglæreren har samtykket $\mathrm{i}$ at hennes skriftlige rapport inngår som en del av datamaterialet. Jeg har meningsfortettet materialet, med vekt på å gjengi yrkesfaglærerens erfaringer korrekt, og vært svært oppmerksom på min egen rolle som yrkesfaglærerens veileder, forsker og på egen førforståelse. Det faktum at jeg ved inngangen av studien hadde store forventninger til resultatene og samarbeid med sosiale entreprenører, ville kunne påvirke resultatene i positiv retning. For å ivareta studiens anonymitet, oppgis ikke yrkesfaglærerens navn som kilde.

\section{Analyse}

Det ble foretatt en analyse med fortetning av de transkriberte intervjuene og yrkesfaglærerens rapport. Stikkord for kodene ble faglighet, selvstendighet, ansvar, samarbeid, deltagelse. Kodene kunne relateres til kategoriene i den didaktiske relasjonsmodellen (Bjørndal \& Lieberg 1978; Hiim \& Hippe 2001) med vekt på sammenheng mellom læreforutsetninger, læreprosess, 
innhold og rammer i opplæringen. Ved analysens siste ledd ble dataene samlet under kategoriene 1) Læreprosessen, samarbeid mellom elevene og arbeidslederen 2) Læreprosessen, samarbeid mellom elevene og yrkesfaglæreren 3) Motivasjon gjennom medbestemmelse og ansvar. Resultatene drøftes under disse temaene og sammenfattes under 4) Samarbeid mellom yrkesfaglærere og arbeidsledere om en alternativ læringsarena.

\section{Motivasjon og mestringsforventninger}

Skaalvik og Skaalvik (2013) mener at mestringsforventning er en nødvendig forutsetning for å ta styring over sitt eget liv, noe som må være målet med all læring. Elevenes forventninger til egen mestring kan gi tydeligere indikasjon på forventede prestasjoner enn evnetester gjør. Albert Bandura mener at personens forventninger er sentrale for motivasjonen. Han bruker begrepet self-efficacy om mestringsforventninger. Ifølge Bandura styres vi av våre forventninger til å mestre, og disse bestemmer i stor grad hvor mye vi anstrenger oss for å oppnå resultatene. Det kan også uttrykkes slik: tror vi at vi vil nå målet, anstrenger vi oss mer enn om vi tror målet er uoppnåelig (Skaalvik \& Skaalvik 2013, 2015).

Bandura (1997) deler mestringsforventninger i to: forventninger om å klare å gjennomføre handlingene som er nødvendige for å nå målet (efficacy expectations), og forventninger om selve resultatet av handlingen (outcome expectations). Han mener at det noen ganger vil være nyttig å skille mellom disse, for eksempel ved veiledning i yrkes- og utdanningsvalg. Da må eleven først tro at hun mestrer å gjennomføre utdanningen, og senere tro at utdanningen vil gi henne den stillingen og det arbeidet hun ønsker.

Bandura har to sentrale bidrag til teorien om mestringsforventninger. For det første handler det om den motivasjonsmuligheten som ligger i rollemodeller og i observasjonslæring. For det andre betydningen av individuell direkte støtte og oppmuntring. Positiv involvering fra voksne er viktig for at elevene ikke skal føle å stå alene med sine egne erfaringer og tolkninger av nederlag og suksess (Bandura 1997; Imsen 1998).

\section{Alternative loeringsarenaer}

Vi ser i dag eksempler på at enkelte alternative arbeids- og læringsarenaer oppnår bedre resultater med unges læring enn den tradisjonelle skolen. Et eksempel er sosiale entreprenører, som driver opplæring og arbeidstrening med elever og unge omtalt som «skoleleie», «late», 
«voldelige», «kriminelle» og «vanskelige». Ofte endrer disse seg og blir ansvarsfulle, motiverte og kunnskapssøkende (Eidsvåg \& Johnson 2010). Da kan vi også spørre: hva gjør disse virksomhetene som skolen ikke gjør? Hva kan vi lære gjennom å samarbeide med dem?

Kravik (2010) har studert ungdommenes erfaringer gjennom Pøbelprosjektet (Eidsvåg \& Johnson 2010). Prosjektet tilrettelegger for mestring, og Kravik mener at det har betydning hvordan ungdommene opplever samfunnsmessige strukturer. Skolen er som oftest preget av et dominerende boklig fokus, dette kan medvirke til at så mange ikke fullfører skole og læretid. Ved å være med å skape noe, delta i et fellesskap, kan de oppleve verdighet og en følelse av å bety noe i en større sammenheng (Kravik 2010).

Ungdom trenger å vite at de faktisk har et valg. Velges noe, må gjerne noe annet velges bort. Resultatene i november 2011 (Rambøll 2011), viste at 64\% av ungdommen i Pøbelprosjektet fra perioden 2008-2010 enten var i jobb, hadde lærlingplass eller gikk på skole. Dette er gode resultater for en gruppe tidligere hadde falt utenfor skole- og arbeidsliv. Disse resultatene tyder på at sosiale entreprenører kan bidra til at flere ungdommer fullfører videregående opplæring enten som skole eller læretid (Rambøll 2011:29).

\section{Sosialt entreprenørskap}

Dette et fenomen som først har blitt kjent på 2000-tallet (Ingstad \& Loga 2016; Spilling \& Johansen 2011). En sosial entreprenør er en person som bevisst tar tak $\mathrm{i}$ et bestemt samfunnsproblem og etablerer en ny løsning. Sosiale entreprenører drives av det å skape sosiale resultater, og er opptatt av å organisere aktiviteten på en måte som gir levedyktig løsning på lang sikt (Ferd 2013). Utfordringer knyttet til integrering, rusmisbruk, arbeidsledighet, eldreomsorg, unge og barn som faller utenfor (Ingstad 2009) løses i dag ofte sammen med eller av sosiale entreprenører. Velferdsstatens evne til å løse slike problemer har ikke økt i samme grad som nasjonens velstand. Dette gir sosiale entreprenører store muligheter. For akkurat som en liten bedrift både kan utfordre og inspirere en stor bedrift, så kan en sosial entreprenør finne løsninger på sosiale problemer der verken offentlige eller private aktører har lykkes (Andersen \& Sandnes 2009). Pøbelprosjektet, Monsterbedriftene, Abildsø gård m.fl. er eksempler på norske sosiale entreprenører som jobber med ungdom, læring og arbeid (Ferd 2013).

Begrepet entreprenør brukes også som adjektiv - entreprenøriell - og karakteriserer typiske trekk ved en aktør. Man kan snakke om entreprenørielle egenskaper, entreprenørielle personer og, for den del, entreprenørielle samfunn. På individnivået er det naturlig å knytte begrepet til det å være proaktiv, evnen til å se muligheter, til å ta initiativ og organisere aktivitet, og jobbe 
målrettet mot et mål. Mens det klassiske entreprenørskapsbegrepet er knyttet til å utvikle ny forretningsmessig virksomhet, vil bruken av termen entreprenøriell være av mer generell karakter knyttet til ulike typer adferd, uten at resultatet er forretningsmessig virksomhet (Spilling \& Johansen 2011:15). Det er her vi plasserer det pedagogiske entreprenørskapet, hvor yrkesfaglæreren er innovatør for didaktisk utvikling i egen praksis.

Pedagogisk entreprenørskap omfatter både de entreprenørielle metodene yrkesfaglæreren benytter i undervisningen og utvikling av nettverk for etablering av alternative læringsarenaer (Kunnskapsdepartementet 2009). En definisjon av begrepet pedagogisk entreprenørskap kan omfatte samarbeid med lokalt arbeidsliv gjennom problembasert læring (PBL), storyline, elevbedrift, gründer-camp, prosjektarbeid, fremtidsverksted og andre læringsaktiviteter. Felles for disse læringsformene er at elevene er aktive og tar i bruk kreative arbeidsformer (Ødegård, 2000, 2014). Pedagoger som har benyttet disse læringsformene finner ikke noe nytt i pedagogisk entreprenørskap (Olofsson 2009), men snarere at dette er nytt navn på gamle metoder. Pedagoger som definerer sitt arbeid som «pedagogisk entreprenørielt» vil muligens se på disse læringsformene som en strategi for læring hvor samarbeidet med arbeidslivet har fått en større plass.

\section{Resultat og diskusjon}

Her presenteres først resultatene fra yrkesfaglærerens dokumenterte utviklingsarbeid, så følger drøfting av analysens følgende hovedkategorier:

- Læreprosessen, samarbeid mellom elevene og arbeidslederen

- Læreprosessen, samarbeid mellom elevene og yrkesfaglæreren

- Motivasjon gjennom medbestemmelse og ansvar.

- Resultatene drøftes under de nevnte kategoriene og sammenfattes under punktet Samarbeid mellom yrkesfaglærer og arbeidsledere om en alternativ læringsarena.

\section{Utviklingsarbeidet}

I det utprøvde samarbeidet mellom en liten sosial entreprenørbedrift og et yrkesfaglig program på en videregående skole underviser yrkesfaglæreren i en filmklasse på program for Media og kommunikasjon. Elevene har mye fravær, enkelte dager opp imot 40\%. Et slikt fravær gjør det vanskelig å organisere læringsaktiviteter. Elevaktive læringsformer som prosjektarbeid er mye 
brukt på skolen, og her er det viktig at alle bidrar, holder avtaler og deltar aktivt. I en filmproduksjon har elevene ulike roller og alle er avhengige av hverandre.

Den pedagogiske plattformen på skolen legger vekt på tilrettelegging for alle. Yrkesfaglæreren strekker seg i praksis langt for å få elevene igjennom. Elevene kan i teorien være borte store deler av undervisningen, delta på et minimum av vurderingssituasjoner og likevel få vurdering. Dermed kan noen elever få opplevelsen av at det ikke er nødvendig å gå på skolen, da fraværet ikke får konsekvenser. For yrkesfaglæreren kan det virke som om elevene mangler ansvarsfølelse for seg selv og sine omgivelser.

I dette tilfelle har yrkesfaglæreren fulgt sine elever fra $\mathrm{Vg} 1$ til Vg3. Hun har sett en endring hos enkelte elever fra å være interesserte og delta i undervisningen til å vise lite faglig interesse, møte trøtte og uopplagte, og med økende fravær. Situasjonen var slik at yrkesfaglæreren følte seg maktesløs og ønsket å prøve ut en annen alternativ læringsarena for et par av sine elever. Dette var bakgrunnen for yrkesfaglærerens utviklingsarbeid i samarbeid med bedriften. Elevenes arbeid $\mathrm{i}$ bedriften besto $\mathrm{i}$ å lage en film som skulle brukes til markedsføring av bedriftens tjenester.

Yrkesfaglæreren definerte elevene som typiske underytere. «Ellers er jentene ressurssterke, og vi lærere har kategorisert dem som typiske underytere. De velger ofte minste motstands vei, og får ikke vist sitt fulle potensiale» (Yrkesfaglærerens rapport). Elevene er altså ressurssterke, men møter sløve og trøtte, og utvikler et stort fravær. Elevene har fortalt yrkesfaglæreren at de ikke er så interesserte i faget, og ikke skal jobbe med det senere.

Begge elevene har gode kunnskaper om film, og vil etter yrkesfaglærerens vurdering kunne lage en film på egenhånd for en ekstern oppdragsgiver. I syv uker jobbet elevene med filmen, parallelt med arbeidet $\mathrm{i}$ bedriften skulle elevene følge noe undervisning på skolen. De skulle selv lage plan, utvikle idé og få eierskap til arbeidet. Læringsprosessen i bedriften var både deduktiv og induktiv. Elevene skulle jobbe for en ekstern oppdragsgiver. Derfor var det naturlig å få oppdraget fra dem, delta på kundemøter og forholde seg mest mulig profesjonelt til bedriften (Yrkesfaglærerens rapport). Yrkesfaglæreren ville være tilgjengelig på telefon og mail om elevene trengte veiledning.

Elevene kunne mesteparten av teorien fra før, og fikk nå muligheten til å bruke den i en reell arbeidsoppgave. Læring og utvikling knyttet til det å ta ansvar, komme presis og forholde seg profesjonelt til en oppdragsgiver ville i hovedsak skje som en induktiv prosess. Teorien vil være erkjennelsen av å mestre et arbeidsoppdrag, og erkjennelsen av at et eksternt oppdrag gir dem 
motivasjon til å komme presis og forholde seg til bestemmelser og avtaler. Erfaringslæringen skulle skje gjennom planlegging og praktisk filming, analyse og refleksjon over arbeidet underveis gjennom flere prosesser, både alene og sammen med de andre i praksisfellesskapet (Wenger 2009). Gjennom dette skulle elevene videreutvikle egen praksisteori (Kolb 2012).

Utgangspunktet for samarbeidet mellom den sosiale entreprenøren og yrkesfaglæreren var å styrke elevenes ansvarsfølelse og mestring. Gjennom samarbeidet skulle elevene lage en film som skulle brukes til markedsføring. Selv om yrkesfaglæreren i sin vanlige praksis følger elevene tett opp og forsøker å ha en god dialog, ønsket hun nå i tillegg å benytte konsekvenspedagogiske prinsipper som en del av elevmedvirkningen. Det ble gjennomført et møte med elevene hvor yrkesfaglæreren benyttet metoden «appell, anmodning og påbud» (Bay 2008). Yrkesfaglæreren forklarer metoden slik:

«Først gjennomføres en individuell samtale med eleven, formålet er å appellere til eleven om hvor viktig det er med tilstedeværelse og nærvær i gruppa. Videre forsøkes det å få eleven til å avdekke grunnene for det store fraværet og skape en dialog om hvilke konsekvenser dette fører til. Samtalen avsluttes med en konklusjon, en konkret avtale. Denne metoden forutsetter at hvis eleven ikke følger opp avtalen, må yrkesfaglæreren umiddelbart ta kontakt for å følge opp. Om dette ikke hjelper, er det siste leddet påbudet. Påbudet gjennomføres som en personlig samtale, men nå med vekt på de direkte konsekvensene handlingen har for elevens status i gruppa» (Yrkesfaglærerens rapport). Formålet med metoden er å tydeliggjøre for eleven gjennom dialog viktigheten av tilstedeværelse og nærvær, og konsekvenser ved å utebli.» (Intervju med yrkesfaglærerne).

\section{Læringsprosessen, samarbeid mellom elevene og arbeidslederen}

Gjennom samarbeid med ekstern oppdragsgiver skulle elevene lage en film. Den skulle brukes til reell markedsføring. Målet var at relevans og medbestemmelse skulle skape motivasjon hos elevene. Yrkesfaglæreren kjente elevene godt gjennom nærmere to år, og definerte dem som underytere, men med god faglig kunnskap. Hun var derfor sikker på om de klarte å lage filmen, men var mer usikker på om de ville møte opp og holde avtalene. Det var jo fravær og liten interesse som for yrkesfaglæreren som var den store utfordringen.

Hun sa: «Jeg har drevet med mye av dette før, men det har vært for elever i øvre sjikt. Det har vært en ekstra belønning til de flinke og ikke en motivasjon for de dårlige» (Yrkesfaglæreren).

Det nye i denne situasjonen var at elevene som dro ut på oppdraget ikke var i øvre sjikt, men var blant de som yrkesfaglæreren ikke hadde like høye forventninger til. Det var nok også derfor yrkesfaglæreren ønsket å benytte den konsekvenspedagogiske metoden med appell, anmodning 
og påbud, under læringsperioden. Hensikten med denne metoden er å tydeliggjøre at valgene og konsekvensene er elevens (Bay 2008).

I avtalen mellom yrkesfaglæreren og elevene skulle elevene være på bedriften omtrent to dager i uken. De andre dagene skulle de møte på skolen og følge undervisningen.

«Elevene hadde fem timer hver tirsdag som de kunne jobbe med dette. I tillegg kunne de få noe tid fra et annet filmfag på onsdager. (...) Innleveringsfristen for elevene var fredag 11.april, så elevene var avhengig av å jobbe med dette utover skolens arbeidstid» (Yrkesfaglærerens rapport).

Elevene møtte lite til undervisningen, og hadde noe kontakt med yrkesfaglæreren, men dette var ikke ofte. De kom og gikk slik de pleide. Da russetiden kom, ble de helt borte.

«De første to ukene var de mye på skolen. De kom til alle timer, fulgte avtaler om å levere dokumentasjon og planer. Fra uke tre begynte fraværet og melde seg hos den ene. Etter 4 uker begynte begge å få ganske stort fravær. I konsekvenspedagogikken er det viktig å være på med en gang elevene sklir ut.» (Yrkesfaglærerens rapport).

Yrkesfaglæreren kontaktet elevene og anmodet de om å møte til en samtale.

«En interessant ting som kom opp da jeg konfronterte elevene, var at de sa de hadde holdt alle avtalene med bedriften og alt var under kontroll. Elevene mente at de gjorde alt de skulle, men ikke «gadd» å være på skolen så lenge det ikke var relevant og viktig.» (Intervju med yrkesfaglæreren).

Det elevene her sa kan tolkes slik at de ikke kunne se sammenhengen mellom det de lærte på skolen og det de tenker vil være deres videre utdanning eller yrkesliv. I Bandura (1997) teori om mestringsforventninger er forventningene om nytteverdi $i$ et fremtidsperspektiv viktig for motivasjonen. Elevene viser at de kan gjennomføre «efficacy expectations» ved å nå målet om å lage filmen, men hensikten med å følge undervisningen på skolen ser de ikke. Dette kan være med å forklare hvorfor elevenes deltakelse er ulik på skolen og i bedriften. Om deres forventninger og betingelse for tilstedeværelse på skolen også er at det skal være umiddelbart nyttig for dem, er det en mismatch mellom skolens tilbud og elevenes forventninger. Filmen ble levert til yrkesfaglæreren og bedriften etter russetiden.

\section{Læreprosessen, samarbeid mellom elevene og arbeidslederen}

Å legge til rette for en god læreprosess er en lærers fremste oppgave. Relasjonene mellom elev og lærer, elevenes lærerforutsetninger, hva som skal læres og hensikten med det, står helt 
sentralt også for en yrkesfaglærer (Hiim 2012, 2013; Hiim \& Hippe 2013). For en arbeidsleder i en bedrift er dette ikke like kjent. Arbeidslederen i dette tilfellet hadde ingen erfaring fra arbeid med elever på videregående skole, heller ikke i filmkunnskap, og var usikker på hvordan han skulle holde kommunikasjonen med dem. Arbeidslederen la til rette for et tidlig møte hvor de etablerte kontakt og hvor arbeidslederen spurte hva de hadde gjort tidligere. Elevene viste da fram filmer de hadde laget før. På spørsmål om arbeidslederen opplevde at elevene hadde faglig kunnskap og viste eierforhold til oppgaven var svaret:

«Når de kom og filmet så stolte jeg på dem i form av teknikk og sånt, jeg spurte hva de trengte, og jeg blandet meg ikke inn i det. Jeg følte nok at de var sikre nok på hva de drev med, og skulle gjøre. De kom for å gjøre en oppgave, hadde med seg alle tingene, snakket sammen og diskuterte hvordan de skulle gjøre det best. Jeg blandet meg ikke inn i det hele tatt og følte ikke at jeg trengte det.» (Intervjuet med arbeidslederen).

Det kommer her klart fram hvordan arbeidslederen ser på sin relasjon til elevene. Han er en leder, men det begrenser seg til å legge til rette rammer for arbeid og læring. Og arbeidslederen så på sin rolle slik:

«Jeg tenker at det ble mer tilrettelegger, jeg har ikke stilt noen krav til dem, jeg tenkte at det ikke var min oppgave, jeg behandlet de som om de var, relativt da, profesjonelle, ... og så tenker jeg at så får skolen plukke mere på det pedagogiske i dette her. Så jeg var mer ... Hva kan dere? Hva kan jeg? Dette kan vi tilby dere, hva kan dere bruke av det, når kan dere møte opp osv. Ja jeg har sett på min rolle som er arbeidsleder - fra bedrift til bedrift.» (Intervju med arbeidslederen).

Jeg mener her at utsagnet viser elevene tillit og respekt, arbeidslederen møter de som likemenn. Det viste seg at ved gjennomføring av arbeidet i bedriften møtte elevene opp og holdt inngåtte avtaler, og de deltok i arbeidet utover vanlig skoletid.

«... de måtte jo møte opp på morgenen og på kvelden, det var jo utenfor skoletida og utenfor arbeidstida, jeg var skeptisk til om de kom, men det gjorde de.» (Arbeidslederen, intervju).

Arbeidslederen fortalte at elevene møtte kl. 07.30 om morgenen for å spise frokost med de andre ansatte, og ble med ut på oppdrag. Andre ganger måtte de stille opp på ettermiddagen for å bli med på arbeid utover kvelden.

«De måtte jo da reist litt ... så da opplevde jeg at de var ganske positive.» (Arbeidslederen, intervju).

Arbeidslederen opplevde elevene som positive til å lære og til å gjennomføre arbeidet. 
Bedriften selger abonnement på glass og metallinnhenting hos private husstander, og arbeidet må derfor foregår før og etter vanlig arbeidstid for folk flest. Det var derfor nødvendig at elevene møtte til disse tidene for å filme aktivitetene, men å stille til frokost, og hvilke oppgaver de ville bli med på, bestemte de selv. Elevene utviklet ideen for filmen og møtte med alt utstyr på bedriften. De var i dialog med bedriften hele tiden, men det var elevene selv som planla og gjennomførte arbeidet på en selvstendig måte.

«Da de kom og filma så stolte jeg på dem i form av teknikk og sånt, jeg spurte hva de trengte, og jeg blandet meg ikke inn i det ... følte at de var sikre nok på hva de drev med.» (Arbeidslederen, intervju).

Arbeidslederen sier her noe om sin rolle i arbeidet, hvordan han trekker seg tilbake og gir elevene frirom for egen bestemmelse og prosess (Honneth, Willig \& Chrom Jacobsen 2003; Schwencke \& Larsen 2011).

\section{Motivasjon gjennom frirom, medbestemmelse og ansvar}

«De kom for å gjøre en oppgave, hadde med seg alle tingene og snakket sammen og diskuterte hvordan de skulle gjøre det best. Jeg blandet meg ikke inn i det hele tatt og følte ikke at jeg trengte det.» (Arbeidslederen)

Her går det fram av arbeidslederens svar at bedriften ga elevene ansvar og frirom for egen utvikling og produksjon. Betydningen av begrepet frirom her er hentet fra kritisk utopisk teori (Aagaard Nielsen 1996), og understreker at i tillegg til behovet for rom og tid, må det også bygges inn strukturer som tar vare på demokratisk atmosfære av aksept for kritiske innspill og fellesskap utenfor ledelsens ønske om kontroll (Nielsen, Nielsen, Munk-Madsen \& HartmannPetersen 2010). Dette begrepet legger vekt på individets umiddelbare opplevelse av anerkjennelse og aksept (Honneth et al., 2003; Schwencke \& Larsen 2011).

Når det gjaldt forventninger og forutsetninger, så kjente arbeidslederen ikke til elevenes bakgrunn. Da vi under intervjuet kom inn på om han trodde elevene hadde lært noe på bedriften som de ikke lærte på skolen, og om han hadde opplevd dem som interesserte i det arbeidet de skulle gjøre, sa arbeidslederen:

«Nå har jeg ikke fått filmen ennå, det har jo vært russetid så jeg har vært litt snill, men jeg har opplevd at de har gjort det de har sagt de skal gjøre og blitt med på alt de har fått mulighet til, det er heller vi som ikke har gitt dem muligheter nok.» (Intervju med arbeidslederen). 
Dette viser igjen arbeidslederens romslighet. Den er basert på tillit og forventninger. Elevene har kanskje følt dette i sitt samarbeid med han, noe som kan ha bidratt til deres motivasjon til å møte opp og utføre arbeidet.

I denne studien kommer det klart frem at yrkesfaglæreren og arbeidslederen har ulike forventninger til elevene. Dette har basert seg på deres kjennskap til elevenes læringshistorie, hvor læreren har erfart elevene som lite interesserte for læring og hvor arbeidslederen kun hadde noen forventninger om at et arbeid skulle utføres av elever. Arbeidslederen hadde ingen kunnskap om film og hadde klare forventninger til at dette kunne elevene mye om. Nettopp det at arbeidslederen ikke kunne noe om det faglige, og at det ble klart kommuniserte til elevene, bidro til at det indirekte ble lagt et ansvar på elevene basert på tillit. Arbeidslederen forventet at her kom det to med fagkunnskap, og viste tillit ved at han trakk seg tilbake. I tillegg sa han at det bare var å spørre om de trengte noe. Arbeidslederen viste tillit og ga et frirom. Samtidig gjorde han det klart at han ville være der.

I følge forskning (Katz et al. 2009) er det viktig for ungdom i overgangen mellom grunnskolen og videregående skole at det gis ansvar og mulighet for selvstendig arbeid, men at det også er viktig med oppfølging av en lærer. I denne studien kan det være at nettopp arbeidslederens ærlige forventninger til faglig arbeid og støttende nærhet bidro til å motivere elevene. De ville kanskje ikke skuffe den som viste dem tillit.

Tillit, slik det det her brukes, forstås som et sentralt kjennetegn på gode relasjoner (Drugli 2012). I undervisning og læring, hvor spørsmål stilles, kan for eksempel faglige samtaler om arbeid være et viktige bidrag for å belyse relevans, mening, tilhørighet og sammenheng. En god relasjon bygger ofte på at man har gjensidig tillit til hverandre (Nordahl 2005), og relasjonen mellom den som skal lære og den som lærer fra seg har derfor stor betydning for opplevelsen av å føle seg vel. Tillit er avhengig av at man vil hverandre vel. Derfor kan en elev virke likegyldig overfor yrkesfaglæreren hvis han ikke opplever at yrkesfaglæreren virkelig vil han vel (Drugli 2012). Når den som lærer fra seg fremstår som trygg, holder avtaler, er forutsigbar og troverdig, vil han oppnå tillit (Nordahl 2005). Det gjenspeiler også et godt samarbeide mellom bedrifter og fagfolk, der man samarbeider for å løse arbeidsoppgaver best mulig (Wenger 2009).

Arbeidslederen møter her elevene som profesjonelle i arbeidet med en filmproduksjon, en arbeidsoppgave med høy relevans for elevenes læring og interesser (Haaland 2010; Hiim, 2013; Sylte et al. 2011). Denne arbeidssituasjonen skal gi relevans på en annen måte enn det er mulig 
å få til på skolen. Yrkesfaglæreren forteller at det de ofte gjør på skolen er å lage case som f.eks.: «Du har blitt ansatt i Amnesty Internasjonal som vil du skal laget en film om ... Et konstruert tilfelle, laget så virkelighetsnært som mulig.» Dette kan skape en form for relevans (Lave 2009), men det gir ikke elevene den samme følelsen som et virkelig oppdrag.

Opplevelsen av å være i et praksisfellesskap viser arbeidet som en del av en større sammenheng (Wenger 2009). Det å erfare og bli gitt tillit, møtes som likemenn i meningsfullt arbeid uten å måtte forholde seg til det konstruerte med kriterier, læringsmål og pensum, gir elvene mulighet for personlig utvikling, en mulighet skolefellesskapet i dag ikke i liten grad kan gi. Yrkesfaglæreren ble spurt; «Kan du beskrive i detalj en situasjon som du mener elevene lærte mye av da de var i praksis i bedriften?», og svarte:

«[...] de møtte opp og forpliktet seg veldig til dette prosjektet. I forhold til min erfaring fra skolen og situasjonen de var i, var det nytt at de i starten forpliktet seg veldig til prosjektet. Selv om de var lite på skolen, så møtte de alltid opp til de avtalene de hadde med arbeidslederen i bedriften, svarte arbeidslederen på mail, og tok de ansvar i produksjonen. De ansatte i bedriften hadde jo ingen erfaring i forhold til hvordan ting skal være filmatisk og slik, og det gledet meg veldig å høre bedriften si at elevene tok ansvar. Arbeidslederen fra bedriften fortalte, at under filming av et intervju, ville han at elevene helst skulle filme stående, mens de mente at det ville bli best gående. Akkurat den senen har jeg sett, og den fungerte faktisk veldig bra. De hadde da trumfet igjennom at de ville ha det slik, selv om lederen i bedriften helst ville ha det stående. Da tenker jeg at de viser evne til å ikke ta ting bare slik det faller seg, og la tilfeldighetene bestemme, men at de selv har en tanke og regi på hva de vil få ut av det. Og det syntes jeg var veldig positivt å hører, en ting er å gjøre det med venner som du kjenner og sånn, en annen ting er med folk du ikke kjenner.» (Intervju med yrkesfaglæreren)

Som det går fram av sitatet, viser yrkesfaglæreren stolthet over elevenes evne til å ta ansvar, og uttrykker at hennes forventninger ikke stemte med virkeligheten, og at elevenes ansvar, initiativ og faglighet gir henne ettertanker. Vi ser i motivasjonsforskning at relasjoner mellom lærer og elever har stor betydning. Det påpekes at elevens oppfatning av den som lærer fra seg, lærer eller yrkesutøver i praksis, har mest betydning for motivasjonen for skolearbeid og læring (Hattie 2009; Overland \& Nordahl 2013; Patrick et al. 2011). Det er vanskelig å bygge relasjoner når elevene har stort fravær. Ofte har elever stort fravær fra starten av skoleåret og behovet for alternative læringsarenaer og eksterne samarbeidspartnere er tidlig til stede. Jeg mener derfor det er viktig at yrkesfaglærere bygger nettverk som baserer seg på ulike bedrifter. Samarbeid med bedrifter med ulik kompetanse kan gi yrkesfaglærerne mulighet til å differensiere læringsprosessene til elevene. Alle elever bør få tilpasset undervisning. Det er derfor viktig at yrkesfaglærerne har nødvendig kompetanse og nettverk, dette bør gjenspeiles i yrkesfaglærerutdanningene. 


\section{Samarbeid mellom yrkesfaglcerere og arbeidsledere om en alternativ loeringsarena}

Ved starten av forskningsarbeidet hadde jeg en forventning om at en alternativ læringsarena hos en sosial entreprenør ville bidra til økt motivasjon for læring og arbeid enn på en tradisjonell læringsarena. I det tilfellet som her er presentert viser dette seg i stor grad.

Skolen i denne studien legger stor vekt på oppfølging av elevene. Lærerne strekker seg langt for å støtte elevene, og elevaktive entreprenørielle læringsformer og interessedifferensiering (Haaland 2010; Sylte et al. 2011), benyttes i utstrakt grad. Elevmedvirkning og relevans viste seg likevel å ikke være tilstrekkelig for at alle elevene skal møte til undervisningen. Hva var det som gjorde at de i møte med bedriften endret adferd, møtte opp, holdt alle avtaler og produserte filmen selvstendig?

I materialet kommer det tydelig fram at yrkesfaglæreren og arbeidslederen $\mathrm{i}$ bedriften møtte elevene med ulike forventninger. Yrkesfaglæreren møtte elevene med appell om deltagelse og konsekvenser ved å utebli. Dette var helt naturlig for yrkesfaglæreren, basert på hennes erfaringer med elevene over to år. Arbeidslederen kjente ikke til elevene, og hadde ikke mottatt informasjon fra yrkesfaglæreren om at elevene kunne utebli fra arbeidet og dermed ikke produsere filmen. Arbeidslederen møtte elevene som likemenn, profesjonelle filmfolk. Måten de ble møtt på (Honneth et al. 2003), tilliten de ble vist (Drugli, 2012; Nordahl 2005), frirommet (Aagaard Nielsen 1996; Schwencke 2006) som ble gitt dem, og deltagelsen i praksisfellesskapet (Katz et al. 2009; Lave \& Wenger 2004; Wenger 2009), kan være faktorer som virket motiverende på dem. Opplevelsen av å bli vist tillit og forventninger til at de kunne utføre arbeidet motiverer til å gjøre arbeidet. Hvem vil skuffe en som viser tillit og har realistiske forventninger til seg?

I dette oppdraget fikk eleven en virkelig arbeidsoppgave i en bedrift. De utførte nyttig og viktig arbeid for andre, både selvstendig og i et praksisfellesskap. Elevene kunne her sanse pulsen i et samarbeidende praksisfellesskap, og gjennom det se sin egen rolle som yrkesutøver. På den måten ble helheten i en produksjon klarere enn det som er mulig på en ordinær skolearena (Haaland 2010; Hiim 2013; Hiim \& Hippe 2001; Schwencke 2006). Dewey (2005) sier at skoleundervisning er verdifull dersom den skaper et ønske om fortsatt vekst, og dersom læringsprosessene tilrettelegges på en slik måte at elevens ønske rent faktisk kan tilfredsstilles. Evnen til å lære av erfaring fører til dannelse av vaner. Videre sier han at aktive vaner involverer 
tenkning, oppfinnsomhet og initiativ til å bruke evner for å nå nye mål. På den måten adskiller de seg fra rutinemessige vaner, som hemmer utvikling (Dewey 2005).

Det er nettopp dette jeg tror elevene opplevde i bedriften sammen med arbeidslederen. Der var det ikke etablert noen rutiner, det var snarere usikkerhet om hva som ville dukke opp og elevene fikk muligheter til å bruke sine kunnskaper og kreativitet, de fikk fritt tenke og utvikle et produkt selvstendig, men i et felleskap til nytte for alle og med ansvar for produksjonen. Dette kan kanskje også forklare hvorfor elevene fortsatte sin passive adferd på skolen og ikke tok den aktive holdningen med seg tilbake.

Det mest betydningsfulle den sosiale entreprenøren gjorde var å møte elevene med tydelig respekt og tillit til deres faglighet (Patrick et al. 2011). I tillegg ble elevene invitert inn $\mathrm{i}$ et praksisfellesskap for å produsere en film, dvs. gjøre en reell arbeidsoppgave selvstendig, men likevel i samarbeid med andre. På spørsmål om hva yrkesfaglæreren kan gjøre for at hans elever får utvikle seg på en slik arena, viste resultatene at forankringen av samarbeidet mellom yrkesfaglæreren og den sosiale entreprenøren om å skape en felles forståelse av læreprosessen er avgjørende.

I denne studien viser resultatene at elevenes motivasjon for arbeid og læring økte i perioden de var i bedriften. Både yrkesfaglæreren og arbeidslederen støtter dette. Det er ikke foretatt en måling om økt motivasjon, men studien viser at elevene kan utføre selvstendig fagarbeid og møte opp til avtalte tider på bedriften. På skolen har det ikke ført til redusert fravær, så resultatene kan tolkes til at arbeid hos en sosialentreprenør kan øke elevenes deltagelse og ansvar for egen læring, men samarbeidet mellom bedriftene og yrkesfaglærerne er helt avgjørende. Spørsmålet blir da hvordan vi skal gjøre det?

Samarbeid mellom skole og bedrift viser seg å kunne gi elever muligheter til å lære utover den ordinære undervisningen, så hvordan vi skal utvikle kompetanse for samarbeid mellom skole og bedrifter er viktig. Denne studiens analyser viser at både yrkesfaglæreren og arbeidslederen legger vekt på forankring av samarbeidet for å skape felles forståelse av læreprosessen og samarbeidet. Begge var mer usikre på hva samarbeidet før og under oppdragsperioden skulle brukes til, hvilken informasjon yrkesfaglæreren skulle gi, og hva arbeidslederen hadde bruk for. Et eksempel på dette er svaret på oppfølgingsspørsmål til arbeidslederen, om han opplevde elevene som helt vanlige ungdommer. Med et smil svarte han «Ja, pliktoppfyllende og litt sløve, men det er man jo». I dette tilfellet var elevenes læreforutsetninger ukjente for arbeidslederen, det mente arbeidslederen var en fordel for å kunne møte elevene som likemenn. 
Å kunne møte elevene med blanke ark var noe han så som svært viktig for å skape en god dialog og et godt praksisfellesskap. Yrkesfaglæreren derimot, mente at hun skulle møtt arbeidslederen tidligere og informert om elevenes situasjon. Det vil si det motsatte av hva arbeidslederen erfarte å ha behov for. Når arbeidslederen ønsket mer samarbeid med yrkesfaglæreren, var det knyttet til informasjon om antall undervisningstimer, rolleforståelse, fraværsrapportering og omfang av involvering i opplæringen i bedriftsperioden. Dette var forhold som ikke var avklart i utgangspunktet, og som arbeidslederen løste ved å la elevene jobbe selvstendig og selv avgjøre når de skulle jobbe med filmen osv., noe som viste seg å være meget positivt.

Det er her en balanse mellom hvor mye informasjon skolen skal gi om innhold, rammer, læreforutsetninger og vurdering, og hva som er nødvendig for at det skal bli en god alternativ læringsarena. Grenseoppgangen mellom elevenes egen opplevelse og et reelt oppdrag blir dermed uklar. For den sosiale entreprenøren som deltok i studien var det ikke viktig å kjenne til elevenes bakgrunn og læreforutsetninger. Han trodde ikke at det var forskjell på om elevene var ute i bedrift hos sosiale entreprenører eller i vanlige kommersielle bedrifter. Likevel mente han at det er en forutsetning for en sosial entreprenørers virksomhet å ha forståelse for at folk kan ha ulike utfordringer i livet og at takhøyden hos dem derfor kan være høyere enn i kommersielle bedrifter.

\section{Konklusjon}

Studien viser at samarbeid mellom yrkesfaglærer og sosiale entreprenører kan være en alternativ læringsarena som fører til økt motivasjon hos elever i den videregående skolen. Studiens funn indikerer at et slik samarbeid kan fremme motivasjon, selvstendighet og god faglighet hos elevene gjennom opplevelsen av tillit, frirom og medbestemmelse. Samarbeid mellom skole og bedrift viser seg å kunne gi elever muligheter til å lære utover den ordinære undervisningen. På spørsmålet om hvordan man skal samarbeide for å oppnå dette, viser denne analysen at både yrkesfaglæreren og arbeidslederen legger vekt på forankring av samarbeidet for å skape felles forståelse av læreprosessen og samarbeidsformen. Forankring gjennom god kommunikasjon mellom aktørene vil være viktig for å oppnå samarbeids- og innovasjonskompetanse mellom skole og bedrifter, og må baseres på elevenes, bedriftenes og skolenes behov. Studien konkluderer derfor med at utgangspunktet for en slik samarbeidsarena er at yrkesfaglærere danner et nettverk med sosiale entreprenører og gjennom dette samarbeidet bidrar til å fremme innovasjon på yrkesopplæringens ulike arenaer i videregående skole. Derfor 
bør bachelorstudiet for yrkesfaglærere legge vekt på og til rette legge for utvikling av studentenes innovasjons- og samarbeidskompetanse gjennom hele studiet. 


\section{Referanser}

Aagaard Nielsen, K. (1996). Arbejdets sociale orientering: en industrisociologisk undersøgelse afforholdte imellem arbejdslivsdemokrati og mulighederne for boredygtighed $i$ industrielle moderniseringsprocesser. København: Forlaget Sociologi.

Andersen, G. \& Sandnes, T. (2009). La ballen rulle! I E. Rønnevig, \& B. Schei (Red.), Vilje til endring. Sosialt entreprenørskap på norsk (s. 49-54). Latvia: Dardedze Holography.

Askerøi, E. \& Høie, M. (2012). Kompetanse for skoleutvikling: hvordan kan loerere utvikle reell endringskompetanse gjennom formell utdanning? (Bind 2012 nr. 8). Oslo: Høgskolen i Oslo og Akershus.

Bandura, A. (1997). Self-efficacy : the exercise of control. New York: Freeman.

Bay, J. (2008). Bemoerkninger til poedagogiske metoder som kan danne grundlaget for social laering. København: TAMU.

Bjørndal, B. \& Lieberg, S. (1978). Nye veier i didaktikken?: en innføring i didaktiske emner og begreper. Oslo: Aschehoug.

Caspersen, J., Garvik, M. \& Wendelborg, C. (2015). Laerlingundersøkelsen 2014 : analyser av variasjoner og sammenhenger Laerlingundersøkelsen 2014 (Bind 2015). Trondheim:

NTNU samfunnsforskning, Mangfold og inkludering.

Dewey, J. (2005). Demokrati og uddannelse. Århus: Forlaget Klim.

Drugli, M. B. (2012). Relasjonen loerer og elev: avgjørende for elevenes laering og trivsel. Oslo: Cappelen Damm

Eidsvåg, E. \& Johnson, Å. F. (2010). Pøbelboka. Oslo: Cappelen Damm.

Ferd. (2013). Sosiale entreprenører. Hentet 20.01.2016 fra

\section{http://www.ferd.no/sosiale entreprenorer}

Grønmo, S. (2004). Samfunnsvitenskapelige metoder. Bergen: Fagbokforlaget

Haaland, G. (2010). Yrkesfagærerens arbeid og utfordringer. I T. L. Hoel, G. Engvik, \& B. Hanssen (Red.), Ny som lcerer: sjansespill og samspill (s. 61-76). Trondheim: Tapir akademisk forlag

Hattie, J. (2009). Visible learning: a synthesis of over 800 meta-analyses relating to achievement. London: Routledge.

Helgøy, I. \& Homme, A. (2013). Overgangsprosjektet - konsekvenser for skolen: evaluering av Ny GIV, Overgangsprosjektet : sluttrapport (978-82-8095-091-8). Bergen: Uni Rokkansenteret.

Hiim, H. (2012). Relevant, praksisbasert yrkesutdanning. I B. Aamotsbakken (Red.), Ledelse 
og profesjonsutøvelse i barnehage og skole (s. 123-137). Oslo: Universitetsforlaget.

Hiim, H. (2013). Praksisbasert yrkesutdanning: hvordan utvikle relevant yrkesutdanning for elever og arbeidsliv? Oslo: Gyldendal akademisk.

Hiim, H. \& Hippe, E. (2001). A utdanne profesjonelle yrkesutøvere. Oslo: Gyldendal akademisk.

Hiim, H. \& Hippe, E. (2009). Undervisningsplanlegging for yrkesfaglaerere (3,. utg.). Oslo: Gyldendal akademisk.

Hiim, H. \& Hippe, E. (2013). A utdanne profesjonelle yrkesutøvere: yrkesdidaktikk og yrkeskunnskap. Oslo: Gyldendal akademisk.

Honneth, A., Willig, R. \& Chrom Jacobsen, M. (2003). Behovet for anerkendelse: en tekstsamling. København: Hans Reitzel.

Høst, H., Nyen, T., Reegård, K., Seland, I. \& Tønder, A. H. (2015). Evaluering av vekslingsmodell i fag- og yrkesopplæringen. Delrapport 1. Oslo: FAFO \&NIFU.

Imsen, G. (1998). Elevens verden : innføring i pedagogisk psykologi (3. utg.). Oslo: Tano Aschehoug.

Ingstad, E. S. \& Loga, J. (2016). Sosialt entreprenørskap i Norge: en introduksjon til feltet. Praktisk økonomi \& finans,(01), 21-33.

Jensen, T. P. \& Larsen, B. (2011). Hvem falder fra- spiller skolen nogen rolle? I C. Helms Jørgensen (Red.) Frafald i erhvervsuddannelserne (s. 205-224). Frederiksberg: Roskilde Universitetsforlag.

Katz, I., Kaplan, A. \& Gueta, G. (2009). Students'Needs, Teachers'Support, and Motivation for Doing Homework: A Cross- - Sectional Study. The Journal of Experimental Education, 78(2), 246-267.

Kolb, D. (2012). Erfaringslæring - processen og det strukturelle grunnlag. I K. Illeris (Red.), 49 tekster om laering (s. 283-298). Frederiksberg: Samfundslitteratur.

Kravik, A. M. (2010). Pøbelprosjektet som mestringsarena: ungdom mellom makt og avmakt (Masteroppgave, Høgskolen i Telemark). Bø.

Kunnskapsdepartementet. (2009). Entreprenørskap i utdanningen: fra grunnskole til høyere utdanning 2009-2014 (Handlingsplan). Oslo: Kunnskapsdepartementet.

Kunnskapsdepartementet. (2013). Lareplanverket i Kunnskapsløftet. Oslo: Departementenes servicesenter.

Kunnskapsdepartementet. ([2013]). Prosjektrapport Ny GIV 2010-2013. Oslo: Kunnskapsdepartementet. Hentet den 30.09.2016 fra https://www.regjeringen.no/globalassets/upload/kd/kampanjer/nygiv/prosjektrapport 
nygiv_2010_2013_8mb.pdf

Kvale, S., Brinkmann, S., Anderssen, T. M. \& Rygge, J. f. (2009). Det kvalitative forskningsintervju. Oslo: Gyldendal akademisk.

Lave, J. (2009). Læringens praksis. I K. Illeris (Red.), Contemporary theories of learning: learning theorists in their own words. London: Routledge.

Lave, J. \& Wenger, E. (2004). Situeret lcering - og andre tekster. København: Reitzel forlaget

Lillejord, S., Halvorsrud, K., Ruud, E., Morgan, K., Freyr, T., Fischer-Griffiths, P., Eikeland, O. J., Hauge, T. E., Homme, A. D., \& Manger,. (2015). Frafall i videregående opplcering: En systematisk kunnskapsoversikt. Hentet den 20.09.2016 fra http://www.forskningsradet.no/servlet/Satellite?c=Rapport\&cid=1254008808778\&pan ame $=$ kunnskapssenter/Hovedsidemal

Lødding, B. \& Holen, S. (2013). Intensivopplaering i eller utenfor klassen?: sluttrapport fra prosjektet Kartlegging av deltakelse, organisering og opplevelse i Overgangsprosjektet innenfor Ny GIV (Bind 42/2013). Oslo: NIFU.

Manger, T., Hansen, O. \& Nordahl, T. (2012). Motivasjon og mestring. Oslo: Gyldendal akademisk.

Markussen, E. (2010). Frafall i utdanning for 16-20 åringer i Norden. København: København: Nordisk ministerråd.

Markussen, E. \& Seland, I. (2012). A redusere bortvalg - bare skolenes ansvar?: en undersøkelse av bortvalg ved de videregående skolene i Akershus fylkeskommune skoleåret 2010-2011 (Bind 6/2012). Oslo: NIFU.

Meld. St. 20. (2012-2013). På rett vei: Kvalitet og mangfold i fellesskolen. [Oslo]: Kunnskapsdepartementet.

Nielsen, L. D., Nielsen, K. A., Munk-Madsen, E. A. \& Hartmann-Petersen, K. (2010). Fleksibilitet, flygtighed og frirum: en kritisk diagnose af det senmoderne arbejdsliv. Fredriksberg: Roskilde Universitetsforlag.

Nordahl, T. (2005). Skolens muligheter i møte med utsatte barn og unge. I Risikoutvikling Oslo: Norsk institutt for forskning om oppvekst, velferd og aldring, c2005 (s. 107-121). Oslo: Norsk institutt for forskning om oppvekst, velferd og aldring.

Olofsson, A. (2009). Entreprenörskap som lokal skol- och samhällsförändring. Hentet den 20.09.2016 fra http://miun.diva-portal.org/smash/get/diva2:224057/FULLTEXT01.pdf Overland, T. \& Nordahl, T. (2013). Rett og plikt til opplaering: om fravaer og deltakelse i skolen. Bergen: Fagbokforlaget

Patrick, H., Ryan, A. M. \& Kaplan, A. (2011). Journal of Educational Psychology, 103(2), 367 
382.

Patton, M. Q. (2002). Qualitative research \& evaluation methods. Thousand Oaks, Calif.: Sage Publications.

Rambøll. (2011). Kartlegging av Pøbelprosjektet (Sluttrapport). Oslo.

Sandal, J.-U. (2007). Sosial-entreprenøren: agent med rett til å endre. Oslo: Kolofon.

Schwencke, E. (2006). Free space in action research and in project oriented traineeship. I Action and interactive research (s. 371-387). Maastricht: Shaker

Schwencke, E. \& Larsen, A. K. (2011). Spenningsfeltet mellom "nytte" for bedriften og "frirom" for studenten: et samarbeidsprosjekt mellom skole og arbeidsliv for gjensidig påvirkning og ønske om forandring. Hentet den 20.09.2016 fra http://www.ha.ax/files/nordyrk_2011.pdf

Skaalvik, E. M. \& Skaalvik, S. (2013). Skolen som laeringsarena : selvoppfatning, motivasjon og laering (2. utg. Oslo: Universitetsforlaget

Skaalvik, E. M. \& Skaalvik, S. (2015). Motivasjon for lcering : teori og praksis. Oslo: Universitetsforlaget

Spilling, O. R. \& Johansen, V. (2011). Entreprenørskap i utdanningen: perspektiver og begreper (Bind 4). Oslo: NIFU.

Stamsø, C. D. (2012). Frafall i yrkesfaglig opplcering : opplevelse av sammenheng og mening i yrkesutdanningen, Masteroppgave, Institutt for spesialpedagogikk, Universitetet i Oslo

Stene, M., Haugset, A. S. \& Iversen, J. M. V. (2014). Yrkesretting og relevans i fellesfagene: en kunnskapsoversikt (978-82-7732-191-2). Steinkjer: Trøndelag forskning og utvikling.

Sylte, A. L., Haaland, G., Hansen, K. \& Dahlback, J. (2011). Yrkesdidaktisk kunnskapsutvikling og implementering av nye læreplaner (KIP) : veien til yrkesrelevant opplæring fra første dag i Vg1 : rapport fra et aksjonsforskningsprosjekt knyttet til implementering av nye læreplaner i ulike yrkesfaglige utdanningsprogram. I (Bind 1). Hentet den 20.09.2016 fra https://fagarkivet.hioa.no/jspui/handle/123456789/204

Wenger, E. (2009). A social theory og learning. I K. Illeris (Red.), Contemporary theories of learning (s. 209-219). London: Routledge.

Ødegård, I.K.R. (2000). Pedagogisk entreprenørskap: en innovasjonsstrategi i opplaering og utdanning. Kristiansand: Høyskoleforlaget

Ødegård, I.K.R. (2014). Pedagogisk entreprenørskap i loererutdanningen: en framtidsrettet loringsstrategi: Cappelen Damm akademisk. 